\title{
WELFARE-TO-WORK EXPERIENCES WITH SPECIFIC Work-First PROGRAMMES IN SELECTED COUNTRIES
}

\author{
WOLFGANG OCHEL \\ CESIFO WORKING PAPER NO. 1153 \\ CAtegory 3: Social Protection \\ MARCH 2004 \\ An electronic version of the paper may be downloaded \\ - from the SSRN website: Www.SSRN.com \\ - from the CESifo website: www.CESifo.de
}




\title{
WELFARE-TO-WORK EXPERIENCES WITH SPECIFIC WORK-FIRST PROGRAMMES IN SELECTED COUNTRIES
}

\begin{abstract}
This paper reviews the evidence of specific mandatory work-first programmes (job search assistance and workfare) for welfare recipients in the United States, the United Kingdom, Denmark, the Netherlands and Germany. It primarily refers to experimental and econometric evaluations. The effectiveness of specific programme elements in promoting the transition from welfare to work is compared. The advantage of combining work-first with training programmes and inwork benefits is discussed. Some policy conclusions are drawn.
\end{abstract}

JEL classification: H53, I30, J20.

Keywords: welfare-to-work, evaluations.

\author{
Wolfgang Ochel \\ Ifo Institute \\ Poschingerstrasse 5 \\ 81679 Munich \\ Germany \\ Ochel@ifo.de
}

The author thanks the Deutsche Forschungsgemeinschaft for financial support (DFG grant No. WE 2815/1). Comments and support by Rebecca Blank, Peter Jensen, Charles Michalopoulos, Alexander Spermann, Rik van Berkel, Bas van der Klaauw and Martin Werding are gratefully acknowledged. 


\section{Welfare-to-Work Experiences with Specific Work-First Programmes in Selected Countries}

\section{Introduction}

In the past two decades the system of basic social protection has been realigned in some OECD countries. The reforms are marked by a change from passive to active social policies with the aim of integrating recipients of social benefits into the regular labour market. These welfare-to-work polices include financial stimuli (in-work benefits, cuts of other benefit entitlements), work-first measures (job search assistance and workfare), training and skill development and work support subsidies (like childcare and transportation assistance).

Most evalua tions of welfare-to-work policies have been primarily directed at measuring the combined effects of all policy measures. There is very little knowledge of the effects of specific instruments. This knowledge, however, is crucial in order to design welfareto-work policies adequately. This paper will review the evidence of specific mandatory work-first (or employment) programmes. It will primarily refer to experimental and econometric evaluations and cover employment programmes in the United States, the United Kingdom, Denmark, the Netherlands and Germany.

\section{Welfare-to-work policies in selected countries}

The traditional welfare system of most OECD countries can be characterised as being passive. Benefits are provided to secure a minimum standard of living, and recipients receive the benefits without a strong obligation to look for work. Such social assistance systems lead to welfare dependency. They encourage inactivity and increase the opportunity cost of working in the market. Traditional social security systems push the reservation wage up, shift the wage structure upwards, and limit the demand for workers with low levels of qualification. At the same time they reduce the willingness of welfare recipients to seek work. Consequently, the number of welfare recipients increases as well as the expenditure on welfare.

In the light of the deficiencies of traditional social policy, a transformation towards a more active social policy has been carried out in some OECD countries over the past twenty years. Welfare-to-work policies were begun in the United States in the 1980s and in countries such as the United Kingdom, Denmark, the Netherlands in the 1990s, with initial efforts now being made also in Germany. These policies aim at an integra- 
tion of social welfare recipients into the regular labour market, or in the words of Esping-Andersen, the end of decommodification in the welfare state (Pierson 2001, pp. 422-423). ${ }^{1}$

Welfare-to-work-policies display different features in the individual countries. Firstly, the target groups are different. While in the US single parents are primarily supported, welfare-to-work policies in the European countries are aimed at all social welfare recipients capable of working but une mployed. Secondly, the measures differ from each other. The more liberal countries, like the US and the UK, place relatively strong emphasis on financial incentives and sanctions. The social democratic Scandinavian countries attempt to activate and educate social welfare recipients. The Netherlands, classified along with Germany in the corporatist country group, follow an intermediate course, whereas the welfare-to-work policy in Germany is still underdeveloped (Gilbert and van Voorhis 2001). Irrespective of the general direction of welfare-to-work policies, all countries oblige social welfare recipients to make use of job search assistance and to participate in workfare measures. But here too, the design of the programmes is different.

\subsection{United States}

The US-American welfare-to-work programme consists essentially of two elements. On the one hand, it offers employees in low wage occupations an Earned Income Tax Credit. The tax credit which was introduced in 1975 is designed to provide an incentive to take up a job (Ochel 2003). On the other hand, the US pursues a workfare model. In the 1980s, relatively small-scale workfare programmes were started. After the 1996 welfare reform, most states focussed on getting welfare recipients to work and used workfare to a larger degree than before. As states were allowed to design their own welfare systems, a fair amount of variation in how strictly work requirements were enforced through sanctions exists, however. The requirement of the Personal Responsibility and Work Opportunity Reconciliation Act (PRWORA) that by 2002 the combination of TANF recipients in work-related activities and caseload reductions should reach a total $50 \%$ of the 1996 caseload did not really promote work-related activities. As all states experienced large caseload reductions, the pressure to meet work equirements was much reduced (Blank 2003, p. 51).

1 Parallel to welfare-to work policies, active labour market policies for job promotion among recipients of unemployment benefits have been developed in many countries. 


\subsection{United Kingdom}

Along with the United States, the United Kingdom has had a long tradition of assisting working people who have low incomes. In 1971, a family income supplement was introduced. This was replaced in 1988 by the Family Credit, which in turn was replaced in 1999 by the Working Families Tax Credit and in 2003 by the Child Tax Credit and the Working Tax Credit. Since 1998, this in-work benefit has been supplemented by several New Deal programmes which aim at increasing people's employability and at helping them find work. The programmes vary in a number of ways: target groups, key objectives, eligibility rules, conditions of involvement and type of support offered. The New Deal for Young People (NDYP) is targeted at those 18 to 24. The New Deal for the Long-Term Unemployed (ND 25+) was initiated for those aged 25 and over who are long-term unemployed. Both programmes offer mandatory job search assistance and workfare. The New Deal for Lone Parents (NDLP) is voluntary and mainly consists of job search assistance. Three more ND programmes also exist (Dolton and Balfour 2002).

\subsection{Denmark}

Denmark's welfare to work policy does not provide in-work benefits. It is based on compulsory activation of welfare recipients. Since the mid-1990s, active social policy (ASP) is guided by a "right and duty" principle. This means that an unemployed person has a right to receive assistance but at the same time a duty to participate in ASP measures in return for public financial support. The ASP measures comprise employment and training measures and counselling. Employment measures consist of different types of subsidised employment, where the person on social assistance is temporarily employed in a private or public enterprise or participates in a municipal employment project. The municipal authorities are responsible for ASP measures. As minimum equirement persons under 30 years shall have an offer to participate in ASP before reaching 13 weeks on welfare, while persons over 30 years shall have an offer before reaching 12 months on welfare (Bolvig et al. 2003, pp. 4-5).

\subsection{Netherlands}

Dutch welfare-to-work policy (at the end of the 1990s) aims primarily at welfare recipients who are young or who are long-term unemployed. It consists mainly of three kinds of measures. Employers are encouraged to employ long-term unemployed by means of wage subsidies and reduction of taxes and social security contributions. Moreover, welfare recipients are confronted with obligations which they have to fulfill. Otherwise they will be sanctioned by partial and for temporary withdrawal of the right to receive a ben- 
efit. Finally starting in 1992, a considerable number of workfare programmes have been introduced. These programmes offer subsidised employment with a regular employer, subsidised employment with a municipal employment organisation and social activation for welfare recipients with limited labour-market opportunities; in addition training is offered (van Oorschot 2002).

\subsection{Germany}

Germany has not developed a comprehensive welfare-to-work policy, although the recent labour market reforms of the Schröder Government go in this direction. Nevertheless, a minor workfare programme called "Hilfe zur Arbeit" (help to work) exists since 1961 when the Federal Social Assistance Act was passed. This Law requires recipients to work for their social assistance when work offers are made. For a long time, this condition remained dormant. Only recently do municipalities offer subsidised work in the private sector, public jobs and specific work opportunities to welfare recipients to a larger extent (Voges and Lemnitzer 2002).

\section{Evaluation challenges and methods}

\subsection{Evaluation challenges}

Estimating the effects of the above-mentioned programmes creates evaluation challenges. In order to produce a reliable estimate of a policy effect, one must control for all other environmental influences. This is a difficult task since countries are continuously changing the mix of the programmes. Moreover, the interaction of different programme components has to be taken into consideration. Complementarities between programme components are to be found wherever the effects of one particular policy arrangement depend on the simultaneous implementation of other arrangements (Orszag and Snower 1999, p. 3). In addition, policy effects have to be separated from economic performance effects.

Apart from controlling for other influences, evaluations have to define adequately the outcome indicators of programmes. In addition to employment and income, social benefits such as reduced crime or better health are of interest. Moreover, evaluations should not only provide evidence on short-run outcomes but should include long-run effects. This is especially important for measuring the effects of human capital development. And, finally, evaluations should not only focus on direct effects (treatment effects) but should take into account indirect effects (substitution and dead weight effects), too (Martin and Grubb 2001). 
Evaluations are also confronted with information problems. Welfare-to-work policies have been introduced only recently. Data sets designed to collect information on this new policy approach are only partially available. Another problem arises from the fact that, very often, municipalities design and implement welfare-to-work policies. The programmes are thus diverse and the quality of administrative data sets provided by municipalities varies, too. This creates problems of comparability of evaluations. Furthermore, not all programme elements are easily measured and coded, and it is especially difficult to get information of implementation practices of enacted programme rules (Blank 2002, pp. 1120-21).

\subsection{Evaluation methods}

Different methods are used to determine the effectiveness of welfare-to-work policies. Aggregate analyses measure the influence of these policies on macroeconomic indicators (e.g. employment rates). They are carried out at the regional or national level. In the following, we do not take into consideration macroeconomic evaluations but concentrate on microeconomic evaluations. At the core of microeconomic evaluations lies the assessment of the effects that welfare-to-work programmes have on those directly affected. The effects are measured on the basis of individual data.

Three microeconomic approaches have been mainly used to study the effects of welfareto-work policies. The intention of leavers' studies is to analyse the behaviour and wellbeing of those who leave welfare because of welfare-to-work programmes. These studies generally use administrative and survey data. Persons on welfare at a specific point in time are surveyed at some later point regarding their employment and income situation. Leavers' studies have a great disadvantage, however. They tell us almost nothing about the true effects of the welfare-to-work programmes. At best they provide information on how ex-welfare recipients are faring, but nothing causal about policy can be deducted from these studies (Blank 2002, pp. 1123-24). That is why we do not include leavers' studies in our evaluation survey.

Another approach to study the effects of welfare-to-work programmes are random assignment or social experiments. In this case, the difference between the outcomes for an experimental group and a control group are used as a measure of the programme effect. From a group of potential participants, the experimental group is randomly chosen to receive new programme benefits. The control group is randomly chosen not to receive the new programme benefits and thus is unaffected by the new programme, this being the only difference between the two groups (Schmidt et al. 2001, pp. 23-32). 
When appropriately designed, experimental evaluations are viewed as highly reliable. These experiments may, however, have limitations. This is the case when programmes also influence the control group or when the experimental group is not stable over time. Experimental programmes may have less significant effects than larger or permanent welfare reforms. Moreover, the distributional effects on individual persons within the experimental group cannot be measured. ${ }^{2}$ And last but not least, experimental evaluations are expensive and time-consuming. That is why administrations are reluctant to undertake experimental evaluations (Blank 2002, pp. 1122-23; Garfinkel, Manski and Michalopoulos 1992; Hagen and Steiner 2000, pp. 51-53).

The third evaluation approach uses econometric assessments. In contrast to social experiments, these are based on non-experimental data collection. The main problem of this procedure is to address adequately the problem of a selection bias resulting from non-random participation of individuals in employment programmes. In this case, participation in a measure is correlated with factors that may also influence the success of the measure. In order to (partially) solve the selection problem, two approaches are favoured in the evaluation studies under consideration: the matching method includes the construction of a "comparable comparison group". In this me thod, for every participant an approximately similar person is chosen from the group of non-participants. The attempt is made to consider all relevant variables and to carry out the selection only on the basis of observable factors. The duration model concentrates on the length of employment and unemployment phases and the respective transfer ratios. The selection process is typically modelled explicitly with respect to unobservable heterogeneity (Heckman et al. 1999; Schmidt et al. 2001, p. 125).

With the aid of social experiments and econometric evaluations, only the direct and not the indirect effects of welfare-to-work measures are captured. These include the deadweight, substitution and displacement effects as well as circular macroeconomic effects.

\section{Job search assistance}

Job search assistance is provided by municipal agencies or other public employment services (PES) and comprises many different types of services. One of them is jobbroking, which consists of the registration of job vacancies, updating the registers and making information available to unemployed welfare recipients. Other services consist of initial interviews at the PES offices, organising collective information sessions or job

2 Experiments can, however, be used to estimate changes in the distribution of earnings, income, etc. as a whole (Bitler, Gelbach and Hoynes 2003). 
clubs, in-depth counselling at some stage during unemployment, etc. Self-motivated, unemployed welfare recipients make use of these opportunities on their own initiative. However, obligations to participate in assistance measures are frequently necessary. Most countries intervene during an unemployment spell by obliging unemployed welfare recipients to report on their independent job-search efforts, to attend intensive interviews, to apply for vacant jobs proposed by the employment agencies, to negotiate an individual action plan, etc. These obligations are usually combined with intensive monitoring and the use of sanctions (OECD 2001, pp. 35-48).

The aim of job search assistance is to make the matching process more efficient, e.g., to increase the number of successful matches at a given number of vacancies and job seekers. A more efficient matching process tends to raise employment. Apart from lowering reservation wages, it reduces hiring costs and thereby increases the expected returns of firms to posted vacancies. If more vacancies are posted, employment goes up. At the same time a higher matching efficiency increases the bargaining position of firms vis-àvis employees searching for a job. Firms can negotiate lower real wages, which, too, works in the direction of increasing employment. These treatment effects may, however, be compensated by employment reducing locking-in effects. They are the result of participants not exiting from job search assistance programmes before they are completed (Calmfors et al. 2001, pp. 75-78).

\subsection{Non-compulsory job search assistance}

There are not many countries that offer non-compulsory job search assistance. One example is the United Kingdom, where the New Deal for Lone Parents (NDLP) is one element of the Government's welfare-to-work strategy. NDLP is a voluntary programme introduced nationally in October 1998 aimed at helping lone parents into work, improving their job readiness and supporting them in finding employment. ${ }^{3}$ The key feature of the programme is a network of personal advisers who offer work-related guidance through a series of interviews and contacts with participants.

Rigorous evaluations of the NDLP programme are the ones provided by Evans et al. (2003) and Lessof et at. (2003). The evaluations are based on face-to-face interviews with around 1,250 participants and a carefully matched sample of around 1,250 nonparticipants. About 317,000 lone parents participated in NDLP between October 1998

\footnotetext{
3 Participation in the NDLP is not compulsory, but attendance at a work-focused interview was made obligatory for all benefit claimants in the ONE pilots. These provide a single point of entry for unemployment and other benefits, bringing together the Employment Service, local authorities and Benefits Agency staff to offer advice in one place. Within the ONE programme, interviews are now scheduled to take place annually.
} 
and September 2002. In May 2002, nine percent of lone parents on Income Support took part in the programme. This is a low coverage. The main reasons lone parents gave for not participating were the desire to look after their children and not wanting help in their search for work (Evans et al. 2003, ch. 2).

Although the aggregate impact was limited by low take-up rates, the NDLP was successful for those who used it. Six months after participation, 43 percent of participants had entered full-time and part-time work compared to 19 percent of matched nonparticipants. This suggests that 24 percent of lone parents found work who would otherwise not have done so (Lessof et al. 2003, p. 110 and Table 1). The effectiveness of NDLP is due to highly motivated and committed personal advisers, their caseload management skills and their autonomy. There is no evidence suggesting that NDLP jobs are not sustainable. On the whole, participants left jobs less quickly than non-participants. Around 29 percent of participants returned within 12 months from work onto Income Support (Evans et al. 2003, p. 93).

The NDLP is cost effective. During fiscal 2000/2001 the government spent $£ 41$ million on the programme. The NDLP resulted in over 26,000 additional job entries from lone parents who joined it. Expenditure per job was $£ 1,570$. The average in-work earning per job amounted to $£ 115$ per week, that is $£ 5,970$ per year. The NDLP thus provided a net gain to society of $£ 4,400$ per job and a total net benefit of $£ 115$ million. These figures are based on the assumption that the 26,000 jobs did not displace other employment which is, however, not realistic (Evans et al. 2003, pp. 91-92).

\subsection{Sanctions and monitoring}

Sanctions imposed on welfare recipients not complying with job search requirements and a close monitoring and counselling by welfare agencies have a positive effect on participation in job search programmes and on job search behaviour. They increase the transition rate from welfare to work. Van den Berg et al. (2002) who studied the behaviour of welfare recipients in the city of Rotterdam found that the transition rate from welfare to work was about twice as large after sanctions were introduced than before. Although most benefit sanctions have only been applied for one or two months and the maximum reduction was 20 percent of welfare benefits, the effect on search behaviour was relatively large. Apparently, marginal utility levels of welfare recipients are high, and/or consumption smoothing is so difficult that welfare recipients wanted to earn money.

The US welfare reform programmes launched prior to the passage of the federal welfare reform law of 1996 also had positive impacts. Bloom and Michalopoulos (2001) synthe- 
sised the results from randomised evaluations of 20 mandatory welfare reform programmes in specific states. Five of them were job-search-first programmes, three were mixed programmes (including training) with an employment focus (Table 1). In the five job-search-first programmes, virtually all recipients were required to begin by looking for work for several weeks on their own or through group activities (such as job clubs) that taught job-seeking skills and then helped participants search for jobs. The synthesis report shows that employment in the programme group was more than 10 percentage points higher than in the corresponding control group. Each of the job-search-first programmes increased earnings by at least US\$ 400 per year (Table 1).

Evidence of the impact that monitoring job-search requirements had is also provided by the evaluation of the Maryland Unemployment Insurance Work Search Demonstration (not welfare related), which started in 1993. The normal work search requirement in Maryland at the time was to report two contacts with specific different employers per week. Informing claimants that reported contacts would be verified with the employer reduced the average duration of unemployment payments by 0.9 weeks ( 7.5 percent). Dropping the requirement for reporting contacts increased the duration, relative to a control group, by 0.4 weeks ( 3.3 percent). At the same time, the relaxed treatment increased total annual earnings by about 4 percent. Possible explanations are that job seekers when freed from job search monitoring wait longer for a better paid job, search more efficiently and/or have a stronger bargaining position with potential employers (Benus et al. 1997; OECD 2001, pp. 203 and 229).

The quality of the jobs found by welfare recipients is, however, not just a function of the strictness of job search requirements but is also determined by job-search assistance being offered or not. According to the OECD (2003, p. 213) imposing job-search requirements without at the same time offering job-search assistance can result in entry into low paid jobs, but job-search requirements with intensive employment counselling and additional assistance can improve employment earnings. It is, however, difficult to determine the optimal combination of job search assistance and increased monitoring and sanctioning of job seekers.

\subsection{Timing and intensity of interventions}

Programme designers must also find the optimum timing for imposing job-search requirements. On the one hand, welfare recipients should be given some time to search for a job on their own. Moreover, "dead weight" associated with early interventions should be avoided. On the other hand, longer periods on welfare are associated with reduced 
Table 1: Effects of Job Search Assistance

\begin{tabular}{|c|c|c|c|c|c|}
\hline Study & Programme & Period & Dependent variable & Method; Data & Results \\
\hline \multicolumn{6}{|c|}{ United States } \\
\hline $\begin{array}{l}\text { Bloom, } \\
\text { Michalopoulos } \\
\text { (2001) } \\
\text { Hamilton et al. } \\
(2001)\end{array}$ & $\begin{array}{l}\text { Eight pro- } \\
\text { grammes that } \\
\text { used only manda- } \\
\text { tory employment } \\
\text { services with a } \\
\text { focus on job } \\
\text { search }^{\text {a) }}\end{array}$ & $\begin{array}{l}\text { Began in the late } \\
1980 \text { s and early } \\
\text { 1990s; } \\
\text { Results for three } \\
\text { years after ran- } \\
\text { dom assignment }\end{array}$ & $\begin{array}{l}\text { Employment earnings; } \\
\text { Welfare benefits; } \\
\text { Budget costs }\end{array}$ & $\begin{array}{l}\text { Random assignment } \\
\text { research design; } \\
\text { Data for programme } \\
\text { group and for control } \\
\text { group }\end{array}$ & $\begin{array}{l}\text { Employment in the programme group more than } 10 \\
\text { percentage points higher than in the control group; } \\
\text { Earnings increased by at least } \$ 400 \text { per year with JSF } \\
\text { programmes, increase higher than in education-first } \\
\text { programmes but lower than in mixed programmes; } \\
\text { Welfare benefit reductions; } \\
\text { Budgetary costs reductions higher with JSF pro- } \\
\text { grammes than with mixed programmes }\end{array}$ \\
\hline $\begin{array}{l}\text { Bloom, } \\
\text { Michalopoulos } \\
\text { (2000); } \\
\text { Miller et al. } \\
(2000)\end{array}$ & $\begin{array}{l}\text { Minnesota Family } \\
\text { Investment Pro- } \\
\text { gramme (MFIP) }\end{array}$ & $\begin{array}{l}\text { Began in 1994; } \\
\text { Results for three } \\
\text { years after ran- } \\
\text { dom assignment }\end{array}$ & $\begin{array}{l}\text { Employment earnings; } \\
\text { Welfare benefits; } \\
\text { Budget costs }\end{array}$ & $\begin{array}{l}\text { Random assignment } \\
\text { research design; } \\
\text { Data for programme } \\
\text { group and for control } \\
\text { group }\end{array}$ & $\begin{array}{l}\text { The MFIP evaluations allow measurement of the sepa- } \\
\text { rate impacts of the mandatory employment services } \\
\text { and earnings disregards; } \\
\text { The employment-related services increased employ- } \\
\text { ment and earnings, the financial incentives were criti- } \\
\text { cal for increasing income and reducing poverty }\end{array}$ \\
\hline \multicolumn{6}{|c|}{ United Kingdom } \\
\hline $\begin{array}{l}\text { Evans et al. } \\
(2003) ; \\
\text { Lessof et al. } \\
(2003)\end{array}$ & $\begin{array}{l}\text { New Deal for } \\
\text { Lone Parents } \\
\text { (NDLP) }\end{array}$ & $\begin{array}{l}\text { October } 1989- \\
\text { September } 2002\end{array}$ & $\begin{array}{l}\text { Participation in NDLP; } \\
\text { Employment six } \\
\text { months after pro- } \\
\text { gramme }\end{array}$ & $\begin{array}{l}\text { Interviews with } \\
1,250 \text { participants } \\
\text { and 1,250 non- } \\
\text { participants }\end{array}$ & $\begin{array}{l}\text { Participation in NDLP: } 9 \text { percent of lone parents on } \\
\text { Income Support (IS) in May 2002; } \\
43 \text { percent of NDLP participants have entered work } \\
\text { compared to } 19 \text { percent of matched non-participants; } \\
\text { Around } 29 \text { percent of participants return within } 12 \\
\text { months from work onto IS; } \\
\text { Key factors identified in the effectiveness of NDLP: } \\
\text { Motivation, autonomy and case load management } \\
\text { skills of personal advisers; } \\
\text { NDLP expenditure / } 26,000 \text { add. jobs entries: } £ 1,570 \\
\text { average in work earnings per job: } £ 5,970 \\
\text { net benefit: } £ 4,400 \text { (financial year } 2000 / 01 \text { ); } \\
\text { net total exchequer gain: } £ 41.5 \text { million }\end{array}$ \\
\hline
\end{tabular}




\begin{tabular}{|c|c|c|c|c|c|}
\hline Study & Programme & Period & Dependent variable & Method; Data & Results \\
\hline \multicolumn{6}{|c|}{ Denmark } \\
\hline $\begin{array}{l}\text { Bolvig, Jensen, } \\
\text { Rosholm (2001) }\end{array}$ & $\begin{array}{l}\text { Active Social } \\
\text { Policy (ASP) }\end{array}$ & $1997-1999$ & $\begin{array}{l}\text { Duration of welfare } \\
\text { spells and employment } \\
\text { spells }\end{array}$ & $\begin{array}{l}\text { Duration model; } \\
\text { Longitudinal regis- } \\
\text { terbased data, Aarhus }\end{array}$ & $\begin{array}{l}\text { Counselling and labour market introductions have a } \\
\text { locking-in effect for persons with unemployment as the } \\
\text { only problem; for persons with other problems besides } \\
\text { unemployment they have positive effects both during } \\
\text { the programme and also after, i.e. recipients leave wel- } \\
\text { fare and start to work }\end{array}$ \\
\hline $\begin{array}{l}\text { Bolvig, Jensen, } \\
\text { Rosholm (2003) }\end{array}$ & $\begin{array}{l}\text { Active Social } \\
\text { Policy (ASP) }\end{array}$ & $1997-1999$ & $\begin{array}{l}\text { Duration of welfare } \\
\text { spells and employment } \\
\text { spells }\end{array}$ & $\begin{array}{l}\text { Duration model; } \\
\text { Longitudinal regis- } \\
\text { terbased data, Aarhus }\end{array}$ & $\begin{array}{l}\text { Other ASP (including job search assistance) has detri- } \\
\text { mental effects on the exit rate from welfare spells }\end{array}$ \\
\hline \multicolumn{6}{|c|}{ Netherlands } \\
\hline $\begin{array}{l}\text { Van den Berg, } \\
\text { van der Klaauw, } \\
\text { van Ours } \\
(2002)\end{array}$ & $\begin{array}{l}\text { Dutch welfare } \\
\text { system; } \\
\text { Sanctions (= tem- } \\
\text { porary benefit re- } \\
\text { ductions) imposed } \\
\text { on welfare recipi- } \\
\text { ents not comply- } \\
\text { ing with job } \\
\text { search require- } \\
\text { ments }\end{array}$ & $\begin{array}{l}\text { January } 1994 \text { to } \\
\text { October } 1996\end{array}$ & $\begin{array}{l}\text { Transition from wel- } \\
\text { fare to work }\end{array}$ & $\begin{array}{l}\text { Basic job search } \\
\text { model; } \\
\text { Randomisation in the } \\
\text { sanction assignment } \\
\text { in a duration model } \\
\text { framework; } \\
\text { Administrative data } \\
\text { of welfare recip ients } \\
\text { in Rotterdam }\end{array}$ & $\begin{array}{l}\text { The imposition of sanctions substantially increases the } \\
\text { transition rate from welfare to work. The transition rate } \\
\text { is about twice as large after a sanction than before; } \\
\text { Closer monitoring and counselling by the welfare } \\
\text { agency may also have a positive effect on the job } \\
\text { search behavior of welfare recipients }\end{array}$ \\
\hline \multicolumn{6}{|c|}{ Germany } \\
\hline $\begin{array}{l}\text { Jerger, } \\
\text { Pohnke, } \\
\text { Spermann } \\
(2001)\end{array}$ & $\begin{array}{l}\text { Intensive counsel- } \\
\text { ling by the Mann- } \\
\text { heim Agency for } \\
\text { placement of wel- } \\
\text { fare recipients }\end{array}$ & $\begin{array}{l}\text { July } 1998 \text { to } \\
\text { June } 2000\end{array}$ & $\begin{array}{l}\text { Transition from wel- } \\
\text { fare to work; } \\
\text { Sustainability of jobs }\end{array}$ & $\begin{array}{l}\text { Matching; } \\
\text { Administrative data }\end{array}$ & $\begin{array}{l}\text { Intensive counselling increases the transition rate from } \\
\text { welfare to work by about } 15 \text { percentage points (from } \\
2.2 \text { to } 17.6 \text { percent); } \\
\text { Sustainability of jobs is about the same in the pro- } \\
\text { gramme group as in the control group }\end{array}$ \\
\hline \multicolumn{6}{|c|}{$\begin{array}{l}\text { (a) Job search first (JSF): Atlanta JSF, Grand Rapids JSF, Los Angeles Jobs First Gain, Riverside JSF, and SWIM; } \\
\text { Mixed employment focus: Portland, Project Independence, and Riverside Gain; } \\
\text { Bloom and Michalopoulos included in their comparative analysis } 12 \text { programmes with an education focus. }\end{array}$} \\
\hline
\end{tabular}

Source: Compilation of the author. 
chances of entering the labour market and with welfare payments. It is difficult to establish a general rule for the optimum timing. There is, however, some evidence that job search assistance for young persons should start relatively early (Martin and Grubb 2001, pp. 28-31). Apart from this general rule, optimal timing seems to vary from individual to individual. It makes sense to leave the timing of interventions to the social worker. By providing intensive case-management support, the starting point of the compulsory programme can most probably be determined in the best way. This method is most strongly adopted in the US, in the British New Deal Programme and the "rights and responsibility" clauses in the Danish activation programme (Trickey 2000, pp. 261263).

The success of job search assistance is also influenced by the intensity with which the support is granted. This is shown by a microeconometric evaluation of the Mannheim job placement agency (Mannheimer Arbeitsvermittlungsagentur: MAVA). In the MAVA the staff of the welfare office and the employment office work together closely in the job placement of welfare recipients who are able to work. The main feature is a higher ratio of personal advisers to recipients in comparison to normal welfare and employment offices. A comparison of the MAVA group with a subsequently formed control group (matching), which had a lower adviser-recipient ratio in the same labour market, showed a drastic improvement in the placement of able-bodied welfare recipients participating in MAVA. The transition rate from welfare to work increased by about 15 percentage points (from 2.2 to 17.6 percent; Jerger et al. 2001; Pohnke 2001).

\subsection{Type of means and targeting}

Another decisive factor for the transition from welfare to work is the nature of the job search assistance programme. If welfare recipients are obliged to take part in timeconsuming collective information and counselling sessions, locking-in effects may prevent them from looking for a job. If, however, job search assistance consists of short interviews and individual counselling then locking-in effects do not occur. The analysis of Bolvig et al. (2001, p. 85 and tables 5.2.3 to 5.2.5), which is based on a longitudinal register-based data set covering Aarhus, the second largest municipality in Denmark, clearly showed that locking-in effects exist and prevent welfare recipients from being transferred to work. Interestingly this occurs only with persons who have no negative characteristics apart from being unemployed. For persons with other problems besides unemployment, job search assistance has positive effects during the programme phase. The emergence of locking-in effects only for people with relatively good chances on the labour market is probably because the job search assistance hindered them in realising their market opportunities. 
The Danish evaluation shows that the success of job search assistance also depends on the target group of the programme. For persons with labour market disadvantages, counselling had positive effects during the programme and also thereafter. The positive effects of the counselling programmes might be due to the fact that they contain job search training and guidance, and this is apparently more effective for the most 'difficult' group of welfare recipients. For persons with unemployment as the only problem, counselling and labour market introductions were not successful, with the exception of a positive post-programme effect of persons above age 30 (Bolvig et al. 2001, p. 85). A study by van der Berg and van der Klaauw (2003) of counselling and monitoring of unemployed workers (not welfare recipients!) with relatively good labour market prospects came to similar conclusions. ${ }^{4}$ The authors show that job search assistance did not affect the exit rate to work. Monitoring only caused a shift from informal to formal job search. They acknowledge that the job search assistance programmes studied were of low intensity. They conclude that the more intensive the job search assistance, the higher the exit rate to work and the worse the labour market prospects (individual or macroeconomic), the larger the effect of monitoring on the exit rate to work. In spite of the evidence of these two randomised experiments, job search assistance managers prefer to include participants with good labour market prospects in their programmes (creaming effect). The exit rate to work is relatively high although compared with the results of a control group it is low.

\subsection{Cost effectiveness}

The evaluations we referred to provide little information on the costs and benefits for government associated with job search programmes. The cost of job search programmes is relatively low. In 2000/01, the UK government spent $£ 41$ million on NDLP. At the same time, exchequer savings (savings in Income Support, Housing Benefits, etc. Working Families Tax Credit) amounted to $£ 82.5$ million leading to a total exchequer gain of around $£ 41.5$ million (Evans et al. 2003, p. 92). Bloom and Michalopoulos (2001) show that operating job-search-first programmes costs less than the programmes with mixed activities and education and training activities (per person). If savings in spending on cash welfare benefits and food stamps are deducted, the cost-effectiveness of the programmes gets apparent. The American evaluations demonstrate that reductions in (net) budgetary costs are higher with job-search-first programmes than with mixed programmes (Table 1). This, however, does not mean that job search pro-

\footnotetext{
4 The authors used administrative information on 394 individuals and survey data concerning a social experiment with full randomisation and compliance. Participants in this experiment started to collect unemployment benefits in the second half of 1998 in two Dutch cities.
} 
grammes should be preferred to mixed programmes. Mixed programmes had particularly large, positive impacts on earnings so that they appear to have been more costeffective (Bloom and Michalopoulos 2001, pp. 19-21).

\section{Workfare}

Workfare can be defined as "programmes or schemes that require people to work in return for social assistance benefits" (Lodemel and Trickey 2000). The definition has three elements. First, workfare is compulsory: non-compliance with work requirements carries the risk of a loss or a reduction of benefits. Second, workfare is primarily about work and not training and other forms of activation. Finally, workfare is essentially about policies tied to the lowest tier of public income support. The introduction of work and compulsion tied to the receipt of aid represents a fundamental change in the balance between rights and obligations in the provision of assistance.

There are four main types of activities in which workfare participants are channeled:

- subsidised work in the private economy,

- work in the public sector for a wage income,

- work in the public sector for benefit level pay, and

- social activation seeking to overcome severe barriers to employment.

These are not strict alternatives, and they are often combined. ${ }^{5}$

The main goal of workfare is to increase employment of welfare recipients in the regular labour market. This may result from several mechanisms. Participation in workfare programmes may help to raise the motivation to actively seek for a job. And employers may perceive workfare participants as more attractive than welfare recipients who are openly unemployed. As a result, competition in the labour market will become more intense. This will lead to a reduction of real wages and an increase in employment. Workfare will also raise the productivity of job seekers. All else being equal, this results in an increase in regular employment. But an increase in the productivity of workfare participants may also lead to a rise of their reservation wages thus offsetting the positive effect on regular employment. The strength of these effects is an empirical issue. Again, treatment effects may be compensated by employment reducing locking-in effects (Calmfors et al. 2001, pp. 78-79).

\footnotetext{
Apart from the activities offered, workfare programmes deal differently with the obligatory nature of participation and with sanctions. There is usually a large degree of discretion involved in delivering the programmes. Thus, it is quite difficult to draw conclusions on the effectiveness of 'workfare programmes' in general.
} 


\subsection{Programmes and their evaluation in different countries}

Workfare programmes have found a strong international dissemination since the US made them an important component of the 1996 Welfare Reform. Although workfare programmes had been implemented in the US in the early 1980s (Friedlander and Burtless 1995; Peck 2001), they were not as much in the forefront of social policies as in later programmes. Since the reforms of 1996, workfare programmes have been realised in many US states, including the programmes of the Human Resource Administration of New York City, Wisconsin Works and the programmes in California (Wiseman 2000). The workfare programmes have been evaluated by means of leavers' studies, and in general they have reached the conclusion that caseloads have declined, employment has increased and earnings (but not net incomes) have grown. Leavers' studies, however, again tell us very little about the effects of the new workfare programmes. ${ }^{6}$ As, on the other hand, the federal mandate for experimental evaluations ended with the 1996 reform, and no experimental (or econometric) evaluations of workfare programmes post1996 exist, we do not have solid information on how these workfare programmes functioned in the US (Blank 2002, pp. 1122-24).

Experimental or econometric evaluations of workfare programmes are not only lacking with respect to the most recent U.S. programmes but have scarcely been realised at all. There are some random assignment studies conducted in the 1980s that examined relatively small-scale workfare programmes in the US. Moreover, the New Deal for Young People and the New Deal for the Long-Term Unemployed in the United Kingdom have been evaluated in a methodologically ambitious way as well as Active Social Policy in Denmark. The Dutch workfare programmes and the German "Hilfe zu Arbeit" (help to work) have not been evaluated, either with random assignment experiments or econometrically.

The 1980s' workfare programmes in the US consist of experiments of open-ended work experience such as the West Virginia Community Work Experience. A number of other programmes used unpaid work experience of three months after job search for people who could not find jobs. These included the Arkansas Work Program, the Cook County WIN Demonstration, the Virginia Employment Services Program, and the San Diego Experimental Work Experience Program. Participation in these programmes was 1equired of all eligible AFDC applicants and recipients with school-age children. Net cost per experiment varied between $\$ 118$ (Arkansas) and \$636 (San Diego). The impact on employment and earnings was favourable. Increases in average annual earnings were 1

6 An exception is Cancian et al. (2003), who compare pre-reform leavers with post-reform leavers in the state of Wisconsin. 
to 33 percent above the annual earnings of people in the control group. The impacts on earning were sustained for at least three years after programme enrolment. With the exception of the West Virginia programme, workfare was accompanied by welfare savings (Gueron and Pauly 1991, ch. 1 and Table 2).

In the UK, the New Deal for Young People (NDYP) is a programme with workfare elements. The target group is all 18 to 24-year-olds who have been claiming unemployment benefits (Jobseeker's Allowance, JSA) for a period of six months or more. The design of the programme is as follows: Participants enter a period of intensive job search known as the "Gateway". The Gateway is intended to have a maximum duration of four months but, in reality, this is exceeded for a sizeable proportion of participants (extended Gateway). Participants then enter one of four options: subsidised employment, full-time education and training, the Environmental Task Force or voluntary service. The workfare options last up to six months. They include a one-day-a-week training. Individuals choose which option to enter, although participation in NDYP is compulsory. After the second phase, individuals enter a period known as "Follow-through" which is essentially the same as the Gateway.

The NDYP has been evaluated by Dorsett (2001) using a non-parametric matching approach. The analysis is based on administrative data for all males entering NDYP between September and November 1998, a total of 33,672 individuals. The analysis comes to the conclusion that regular employment is promoted through workfare and especially through subsidised employment (for a comparison with the other NDYP options see the presentation of further results below) (Table 2). ${ }^{7}$ Dorsett's results have been confirmed by a survey of employers who have received a subsidy for six months for employing participants of the NDYP: 51 percent of the recruits were still employed after nine months; 26 percent of the recruitment was fully additional and five percent was partly additional (Hales et al. 2000).

Workfare elements also play a role within the New Deal for People Aged 25 and over (ND 25+). Under the original programme (June 1998 to April 2000), clients entry to the programme typically occurred with a restart interview for those with at least two years of continuous JSA claim. Mandatory interviews with Personal Advisors of up to six months followed. The programme was enhanced in April 2000. In pilot areas, entry occurred after 12 to 18 months of continuous JSA receipt. After a Gateway of typically 13

\footnotetext{
7 The outcome of NDYP is measured by the number of participants not receiving Jobseeker's Allowance any longer. This is, however, not coterminous with being employed. It can also indicate economic inactivity.
} 
weeks a mandatory referral to an Intensive Activity Period (IAP) followed, which consisted of 13 weeks' activity. IAP included subsidised employment, Education and Training Opportunities (ETO) and Work Based Learning for Adults (WBLA). In April 2001, a re-engineering of the programme took place (Wilkinson 2003, ch. 3).

Evaluation evidence exists for the original national programme and for pilot provisions. Lissenburgh (2001) based his evaluation on administrative and survey data for pilot participants and used a matching methodology. He concluded that IAP entrants had a 6.6 percentage point advantage over their comparators with regard to unsubsidised employment exits. Subsidised employment had a positive impact, whereas ETO and WBLA had a negative or no impact. In the last two cases locking-in effects may have played a role (Lissenburgh 2000, p. xxxii). These results have been confirmed by the survey of Hales et al. (2000): 60 percent of the long-term unemployed who have taken over a subsidised job were still employed at the end of nine months (Table 2). The results coincide with the findings of Martin and Grubb (2001, pp. 31-32) that subsidies to private-sector employment can yield significant net employment gains and help to maintain workers' attachment to the labour force.

Positive employment effects have also come from the workfare programme of the Danish Active Social Policy. Danish municipal authorities use different forms of workfare measures: private sector employment programmes (including ordinary or individual job training), public sector employment programmes (including ordinary and individual job training and municipal employment projects), and "other programmes" (including two types of rehabilitation programmes). The analysis of Bolvig et al. (2003) shows that workfare measures improve the chance of leaving welfare dependence. The transition rate from welfare to employment is more than three times as high after the workfare measures have been realised compared to no workfare measures. These favourable effects are due to positive post-programme effects (see below). The increased transition rate from welfare to employment can be due to several factors. Workfare measures may increase the search intensity, for instance due to a higher self-confidence of the jobseeker, improved work habits, or a closer contact to the labour market. Or they may - according to search theory - increase the job offer arrival rate because the qualifications of the job seeker may have improved. 
Table 2: The Effects of Employment Programmes

\begin{tabular}{|c|c|c|c|c|c|c|c|}
\hline Study & Programme & Period & Dependent variable & Method; Data & \multicolumn{3}{|c|}{ Results } \\
\hline \multicolumn{8}{|c|}{ United States } \\
\hline \multirow{6}{*}{$\begin{array}{l}\text { Gueron, } \\
\text { Pauly } \\
\text { (1991) } \\
\text { Table } 1.1\end{array}$} & \multirow[b]{2}{*}{$\begin{array}{l}\text { West Virginia Co m- } \\
\text { munity Work Expen- } \\
\text { ence Program (open- } \\
\text { ended unpaid work) }\end{array}$} & \multirow[b]{2}{*}{$\begin{array}{l}\text { Evalua- } \\
\text { tion } \\
\text { began in } \\
1983\end{array}$} & \multirow[b]{2}{*}{$\begin{array}{l}\text { Earnings; } \\
\text { AFDC pay ments }\end{array}$} & \multirow[b]{2}{*}{ Random assignment } & \multicolumn{3}{|c|}{$\begin{array}{l}\text { Annual impacts for all years of follow-up } \\
\begin{array}{ll}\text { Outcome } & \text { Percentage change over control group level }\end{array}\end{array}$} \\
\hline & & & & & $\begin{array}{l}\text { Earnings } \\
\text { AFDC payments: }\end{array}$ & $\begin{array}{l}\text { Year } 1 \\
\text { Year } 1\end{array}$ & $\begin{array}{l}4 \\
0\end{array}$ \\
\hline & $\begin{array}{l}\text { Arkansas WORK } \\
\text { program (sequence of } \\
\text { group job search and } \\
\text { unpaid work) }\end{array}$ & $\begin{array}{l}\text { Evalua- } \\
\text { tion } \\
\text { began in } \\
1983\end{array}$ & $\begin{array}{l}\text { Earnings; } \\
\text { AFDC pay ments }\end{array}$ & Random assignment & $\begin{array}{l}\text { Earnings: } \\
\text { AFDC payments: }\end{array}$ & $\begin{array}{l}\text { Year } 1 \\
\text { Year } 2 \\
\text { Year } 3 \\
\text { Year } 1 \\
\text { Year } 2 \\
\text { Year } 3\end{array}$ & $\begin{array}{r}33 \\
23 \\
31 \\
-13 \\
-19 \\
-18\end{array}$ \\
\hline & $\begin{array}{l}\text { Cook County WIN } \\
\text { Demonstration (se- } \\
\text { quence of individual } \\
\text { job search and unpaid } \\
\text { work) }\end{array}$ & $\begin{array}{l}\text { Evalua- } \\
\text { tion } \\
\text { began in } \\
1985\end{array}$ & $\begin{array}{l}\text { Earnings; } \\
\text { AFDC pay ments }\end{array}$ & Random assignment & $\begin{array}{l}\text { Earnings: } \\
\text { AFDC payments: }\end{array}$ & $\begin{array}{l}\text { Year } 1 \\
\text { Year } 1\end{array}$ & $\begin{array}{r}1 \\
-1\end{array}$ \\
\hline & $\begin{array}{l}\text { Virginia Employment } \\
\text { Services Program } \\
\text { (sequence of job } \\
\text { search and unpaid } \\
\text { work) }\end{array}$ & $\begin{array}{l}\text { Evalua- } \\
\text { tion } \\
\text { began in } \\
1983\end{array}$ & $\begin{array}{l}\text { Earnings; } \\
\text { AFDC pay ments }\end{array}$ & Random assignment & $\begin{array}{l}\text { Earnings: } \\
\text { AFDC payments: }\end{array}$ & $\begin{array}{l}\text { Year } 1 \\
\text { Year } 2 \\
\text { Year } 3 \\
\text { Year } 1 \\
\text { Year } 2 \\
\text { Year } 3\end{array}$ & $\begin{array}{r}5 \\
14 \\
11 \\
-3 \\
-2 \\
-9\end{array}$ \\
\hline & $\begin{array}{l}\text { San Diego Experi- } \\
\text { mental Work Experi- } \\
\text { ence Program (se- } \\
\text { quence of group job } \\
\text { search and unpaid } \\
\text { work) }\end{array}$ & $\begin{array}{l}\text { Evalua- } \\
\text { tion } \\
\text { began in } \\
1982\end{array}$ & $\begin{array}{l}\text { Earnings; } \\
\text { AFDC pay ments }\end{array}$ & Random assignment & $\begin{array}{l}\text { Earnings: } \\
\text { AFDC payment }\end{array}$ & $\begin{array}{l}\text { Year } 1 \\
\text { Year } 1\end{array}$ & $\begin{array}{r}23 \\
-8\end{array}$ \\
\hline
\end{tabular}




\begin{tabular}{|c|c|c|c|c|c|}
\hline Study & Programme & Period & Dependent variable & Method; Data & Results \\
\hline \multicolumn{6}{|c|}{ United Kingdom } \\
\hline $\begin{array}{l}\text { Dorsett } \\
(2001)\end{array}$ & $\begin{array}{l}\text { New Deal for Young } \\
\text { People (NDYP) }\end{array}$ & $\begin{array}{l}\text { Sept. to } \\
\text { Nov. } \\
1998\end{array}$ & $\begin{array}{l}\text { Not receiving } \\
\text { Job-Seeker's } \\
\text { Allowance (JSA) } \\
\text { (as an indicator for } \\
\text { employment) }\end{array}$ & $\begin{array}{l}\text { Non-parametric } \\
\text { matching; } \\
\text { Administrative data } \\
\text { for all males entering } \\
\text { NDYP between Sept. } \\
\text { and Nov. } 1998\end{array}$ & $\begin{array}{l}\text { Subsidised employment is the most effective means of securing unsubsidised } \\
\text { employment; it is much more effective than the other options: Full-time education } \\
\text { and training, voluntary service and environmental work; } \\
\text { Gateway is less effective than subsidised employment but more effective than the } \\
\text { three other options }\end{array}$ \\
\hline $\begin{array}{l}\text { Lissen- } \\
\text { burgh } \\
(2001) \\
\text { Wilkinson } \\
(2003)\end{array}$ & $\begin{array}{l}\text { New Deal for the } \\
\text { Long-Term Unem- } \\
\text { ployed } \\
(\text { ND } 25+\text { ) }\end{array}$ & $\begin{array}{l}1999 \text { and } \\
2000\end{array}$ & $\begin{array}{l}\text { Employment entry; } \\
\text { Unemployment } \\
\text { exit; } \\
\text { Employability }\end{array}$ & $\begin{array}{l}\text { Matching; } \\
\text { Administrative and } \\
\text { survey data for pilot } \\
\text { participants }\end{array}$ & $\begin{array}{l}\text { Intensive Activity Period (IAP) entrants have a } 6.6 \text { percentage point advantage } \\
\text { over their comparators with regard to unsubsidised employ ment exits; } \\
\text { Employment Subsidy entrants reduced their time on JSA by } 16 \text { percentage points } \\
\text { whereas those on Education and Training Opportunities and on Worked Based } \\
\text { Learning for Adults increased it by } 16 \text { and } 6 \text { percentage points }\end{array}$ \\
\hline $\begin{array}{l}\text { Hales } \\
(2000)\end{array}$ & $\begin{array}{l}\text { NDYP } \\
\text { ND } 25+\end{array}$ & $\begin{array}{l}\text { Sept. } \\
1999 \text { to } \\
\text { Jan. } \\
2000\end{array}$ & Employment record & $\begin{array}{l}\text { Survey of employers } \\
\text { who receive a sub- } \\
\text { sidy for recruiting } \\
\text { ND partic ipants; } \\
3,208 \text { establis hments }\end{array}$ & $\begin{array}{l}\text { Subsidised employment was an effective means of securing sustainable employ- } \\
\text { ment: } 51 \text { percent of NDYP recruits and } 60 \text { percent of ND25+ recruits were em- } \\
\text { ployed at the end of nine months; } \\
26 \text { percent of recruitment was fully and } 5 \text { percent partly additional }\end{array}$ \\
\hline \multicolumn{6}{|c|}{ Denmark } \\
\hline $\begin{array}{l}\text { Bolvig, } \\
\text { Jensen, } \\
\text { Rosholm } \\
(2003)\end{array}$ & $\begin{array}{l}\text { Active Social Policy } \\
\text { (ASP) }\end{array}$ & $\begin{array}{l}1997 \text { to } \\
1999\end{array}$ & $\begin{array}{l}\text { Duration of welfare } \\
\text { spells and employ- } \\
\text { ment spells }\end{array}$ & $\begin{array}{l}\text { Duration model; } \\
\text { Longitudinal regis- } \\
\text { terbased data, } \\
\text { Aarhus }\end{array}$ & $\begin{array}{l}\text { Employment measures: weak locking-in effects, positive post-programme effects; } \\
\text { There is evidence for assigning men to very early participation in employ ment } \\
\text { programmes and women to participation after } 6 \text { months of welfare duration to } \\
\text { achieve the maximum net effect (cost of ASP have not been accounted for); } \\
\text { Considerable short-time recividism of welfare dependence }\end{array}$ \\
\hline $\begin{array}{l}\text { Bolvig, } \\
\text { Jensen, } \\
\text { Rosholm } \\
(2001)\end{array}$ & $\begin{array}{l}\text { Active Social Policy } \\
\text { (ASP) }\end{array}$ & $\begin{array}{l}1997 \text { to } \\
1999\end{array}$ & $\begin{array}{l}\text { Duration of welfare } \\
\text { spells and employ- } \\
\text { ment spells }\end{array}$ & $\begin{array}{l}\text { Duration model; } \\
\text { Longitudinal regis- } \\
\text { terbased data, } \\
\text { Aarhus }\end{array}$ & $\begin{array}{l}\text { Locking-in effects: strong for community jobs, job preparation, public training on } \\
\text { the job and employment project; weak for private training on the job, training on } \\
\text { the job and worktest; } \\
\text { Post-programme effects positive for all workfare categories (not for persons } 30 \\
\text { years and older for some categories) }\end{array}$ \\
\hline $\begin{array}{l}\text { Graversen } \\
(2003)\end{array}$ & $\begin{array}{l}\text { Active Social Policy } \\
\text { (men above } 25 \text { years) }\end{array}$ & $\begin{array}{l}1994- \\
\text { mid } 1998\end{array}$ & $\begin{array}{l}\text { Exit rate from wel- } \\
\text { fare to jobs }\end{array}$ & $\begin{array}{l}\text { Duration model; } \\
\text { Longitudinal regis- } \\
\text { terbased data; } \\
\text { Survey conducted in } \\
275 \text { Danish } \\
\text { munic ipalities }\end{array}$ & $\begin{array}{l}\text { Pre-programme incentive effect: existing; } \\
\text { Locking-in effect: large for public sector employment, not existing for private } \\
\text { sector employment programmes; } \\
\text { Treatment effect: positive, larger for private than for public sector employment } \\
\text { programmes; } \\
\text { Early assignment into a public sector employment programme increases the } \\
\text { length of the welfare spells; early assignment into a private sector employment } \\
\text { programme decreases the length of welfare spells. }\end{array}$ \\
\hline
\end{tabular}

Source: Compilation of the author. 
Starting in 1992, the Netherlands have been introducing a considerable number of workfare programmes. Young unemployed were offered temporary jobs in the public and private sector. For the older long-term unemployed the Jobpool scheme was introduced. Both schemes have been integrated into the Jobseekers' Employment Act. Later on the so-called Melkert I and II programmes were created. Melkert I-jobs, e.g., include subsidised jobs in Dutch municipalities and in the public health sector with an income not exceeding 120 percent of the legal minimum wage. The government considered Melkert I-jobs as regular jobs which, however, they were not. For long-term unemployed on social assistance with limited labour market-opportunities social activation measures have been introduced. Municipalities offer opportunities to participate in unpaid activities. Social activation experiments do not necessarily prepare people for labour market participation (van Berkel and de Schampheleire 2001). Leavers' studies show that participants in workfare measures often find it difficult to enter the regular labour market (van Berkel 2000; van Oorschot 2000). This may be partly explained by the lack of a clear-cut labour market orientation of the Dutch activation policy. However, participants prefer to have a regular job than staying in workfare (van Berkel et al., no year). Apart from leavers' studies, random assignment or econometric evaluations of the Dutch workfare programme do not exist.

The German workfare programme for welfare recipients is called "Hilfe zur Arbeit". The workfare component of social assistance consists of a graduated series of measures which aim at the reintegration of recipients into the regular labour market. For the most employable recipients, the local authorities may provide subsidised work in the private sector on a time-limited basis. For clients who have greater job placement difficulties, community work is available. These public jobs may be paid at a reduced wage level or participants receive social assistance (plus a supplement). At the lowest level, specific work opportunities are offered. Recipients who refuse to participate in "help to work" are supposed to be sanctioned. Leavers studies have been made for Hamburg, Bremen and Berlin. Between a third and a fifth of the workfare participants in 1989 to 1991 have got a regular job in the first months after completing their workfare activity (Voges and Lemnitzer 2002). Experimental and econometric evaluations have not been undertaken. 


\subsection{Timing}

Programme designers must find the optimal timing of starting workfare measures. How long should the unemployed be on welfare before participation starts? Bolvig et al. (2003) investigated timing for workfare measures in Aarhus, Denmark. They have found evidence for assigning men to very early participation in workfare programmes to achieve the maximum net effect, that is to say, the highest exit rate from welfare spells. The reason is that the positive post-programme effect can be enjoyed for a longer period of time the earlier the person begins, while the locking-in effect is quite small for men. Women should start workfare programmes after six months of welfare duration. As with men, by participating earlier, the positive post-programme effect can be enjoyed for a longer period. On the other hand, early participation implies more weight on the locking-in effect, which is significantly negative for women. It should be mentioned that the analysis did not account for the cost of workfare programmes. Instant participation may result in higher costs of administration etc., thereby making instant participation an undesirable policy (Table 3).

The question of timing of workfare measures is also addressed by Graversen (2003). He tries to find out if an early use of workfare measures aimed at welfare benefit recipients in Denmark is successful in reducing the length of welfare spells. In addition to lockingin effects and post-programme (treatment) effects, he estimates the significance of preprogramme incentive effects. They measure the potential increase in the exit rate from welfare to work when welfare benefit recipients are facing the risk of being selected to participate in a workfare programme. The effect is identified by the fact that the intended timing of the programmes differs among municipalities. Some municipalities give workfare offers just a few days after an individual becomes eligible for welfare, others wait almost one year. The principal workfare offers consist of private and public sector employment measures. Graversen uses event histories of 7,602 men above 25 years who began welfare spells during the period from 1994 to mid-1998. ${ }^{8} \mathrm{He}$ uses a duration model framework for his estimates. Although pre-programme incentive effects exist, his estimates of the different programme effects suggest that an early assignment into a public sector employment programme prolongs the welfare spell because of the large locking-in effect. Early assignment into a private employment programme, however, decreases the length of the welfare spell because of the modest locking-in effect and the large treatment effect.

8 Later on the age limit for an ASP offer to welfare recipients within a year has changed from 25 to 30 years. 


\subsection{Type of activities and targeting}

The nature of the workfare programme is another important factor for the transition from welfare to work. It has already been mentioned that workfare takes place by different means. Subsidised employment in the private sector is offered to the most employable welfare recipients; social activation, on the other hand, seeks to overcome severe barriers to employment. Subsidised employment as part of the NDYP was much more effective than participating in the Environment Task Force and voluntary service. The rate of unemployment among those in subsidised employment was lower by nearly 20 percentage points than if they had participated instead in the two other options (Dorsett 2001, Table 5.5). The same is true for the ND 25+. Employment subsidy entrants reduced their time on JSA by 16 percentage points whereas those on work-based learning for adults increased it by six percentage points (Lissenburgh 2001, p. xxxii). Locking-in effects were effective. Differences in the locking-in effects were also found for Active Social Policy in Denmark. The effects were strong for community jobs (communal job), job preparation (igangsaetningsydelse), public training on the job (off. jobtraening) and employment project (beskaeftigelse projekt) and they were weak for private training on the job (privat jobtraening), training on the job (jobtraening) and worktest (arbejds afprovning). (Bolvig et al. 2001, Table 3). The results of Bolvig et al. are confirmed by Graversen (2003). His study shows that locking-in effects are large for public sector employment programmes and not significant for private sector workfare programmes. The success of subsidised employment in the private sector is due to various factors: participants are the most employable, they work in close contact to employers, they can demonstrate their ability in the regular labour market and locking-in effects play a minor role.

The Danish evaluation also shows that the success of workfare programmes depends on the target group the programme aims at. For persons with labour market disadva ntages, workfare has more positive effects than for persons with unemployment as the only problem. Apparently, the more "difficult" group of welfare recipients needs activation more than the other recipients. Workfare is more effective for the young unemployed below 25 than for tho se above 30. And, finally, the employment measures are more successful with male than for female participants. This is due to the high locking-in effects for women compared to the quite small locking-in effects for men. It seems to be the case that women engaged in workfare and having to care for children do not find the time to search for a regular job (Bolvig et al. 2003, p. 17). 


\subsection{Workfare versus job search assistance}

Workfare measures have an overall positive impact on the transition from welfare to regular work. But are they more successful than job search assistance? Dorsett (2001) compared the effects of workfare and the extension of the job search period (extended Gateway) for NDYP participants. The message that emerges from his analysis is that a period of subsidised employment is a more effective means of securing unsubsidised employment than remaining on the Gateway. On the other hand, an extension of job search is more effective than a voluntary service or environmental work in the public sector. There are a number of possible reasons for the relative effectiveness of the extended Gateway. Participation in voluntary service and environmental work may reduce job search for the duration of the option. At the same time, individuals that remain for an extended period on the Gateway still participate in supervised job search, and this may have positive employment effects.

\subsection{Impact on earnings}

In addition to the employment prospects, it is of interest to know how welfare-to-work approaches affect earnings and income outcomes of welfare leavers. Cancian et al. (2003) compare welfare leavers in Wisconsin under early AFDC reforms and under the later, more stringent TANF programme. They consider outcomes for women leaving welfare in 1995, 1997 and 1999. They find that later leavers are more likely to work, but their earnings are lower. They also make a pre-post comparison of individual income experiences, examining a leaver's outcome during welfare receipt with the outcomes a year after leaving welfare. On average, substantial earnings growth is outweighed by declines in benefits, resulting in reduced total measured net income.

\section{Effectiveness of work-first programmes vis-à-vis other measures}

\subsection{Training}

There are debates on the services to be provided to people moving from welfare to work in order to give them optimal support. Are job search or workfare programmes better suited than, for example, programmes that focus on human capital development and provide more training and educational opportunitie s to recipients? Making side-by-side evaluations of job search programmes and education and training programmes in Atlanta (Georgia), Grand Rapids (Michigan) and Riverside Country (California), Hamilton et al. (2001) as well as Bloom and Michalopoulos (2001) in their synthesis concluded that counselling increased employment and earnings more than education and training 
programmes. The same was true when comparing other programmes. ${ }^{9}$ Interestingly, the best results occurred in programmes with mixed activities, such as the Portland JOBS programme. Job-ready participants were required to look for work. Participants with lower levels of education were initially assigned to basic education and training. There was, however, a strong emphasis on employment. Education and training activities were brief, and staff strongly emphasized the importance of finding jobs. Although the aim was to promote a rapid return to employment, members were encouraged to keep searching until they find a 'good' job. The Portland programme showed earnings increases of $\$ 1,200$ a year, whereas earnings in the job-search-programmes increased only between $\$ 400$ and $\$ 800$ a year. Combining job-search assistance with training provisions seems to be an important key to success (Blank 2003, pp. 62-63).

Comparing workfare programmes with training and education, Dorsett (2001) found out that subsidised employment is much more effective than fulltime education and training, whereas the voluntary service and environmental work of the NDYP are roughly as effective as educational measures. Analysing the ND 25+, Lissenburgh (2001) concluded that subsidised employment reduced the time on JSA by 16 percentage points whereas Education and Training Opportunities and Worked Based Learning for Adults increased it by 16 and 6 percentage points, respectively. Bolvig et al. (2003) showed that training measures that are organised in the form of courses and classes have negative effects on the transition from welfare to employment in Aarhus, whereas workfare has positive effects. Having attended training measures lowers the transition rate from welfare to employment to half of the transition rate for non-participants, while participation in workfare raises it substantially. The negative effect of training measures on the exit rate from welfare spells is primarily due to the strong locking-in effect. But postprogramme effects also have negative effects in Denmark, which might have been the result of a rise of the reservation wage of training participants. The results presented here include only short-term effects. In the longer-term, a payback to the education option may be observed.

9 These evaluations had three-year follow-up surveys. If welfare to work participants (and their control groups) are followed up to nine years, those who received more education or training do as well or better than those who were put into work-first programmes (Blank 2002, p. 1147; Hotz et al. 2000). 


\subsection{Financial incentives}

Apart from training, work- first programmes can be compared to financial incentives. An interesting experiment is the Minnesota Family Investment Program (MFIP), offering job search assistance and an income supplement. The MFIP was implemented in 1994 and provided a strong earnings disregard that allowed women to receive some cash assistance until their earnings were about 140 percent of the poverty line (Miller et al. 2000). Participants were also required to participate in mandatory job search programmes. A subset of the treatment group was provided with financial incentives arising from earnings disregards but was not subject to mandatory job search requirements. By randomising participants into both treatment groups and the control group, the separate effects of mandatory job search (on top of financial incentives) and earnings disregards could be explored. Table 3 shows the separate impact of mandatory employment services (on top of earnings disregards) and financial incentives. The employmentrelated services were primarily responsible for increasing employment and earnings but did not increase income substantially. The high earnings disregards had little effect on labour supply and employment but were mainly responsible for the increase in income and the anti-poverty effects (Blank 2002, pp.1148-49). In the words of Rebecca Blank (2003, p.61), the "stick" of mandatory job search requirements increased employment, but by itself this had little effect on overall income as increases in earnings were offset by reduced benefits. But the "carrot" of greater earnings disregards provided an income enhancing effect. When used together, one gets the best possible results: increased work and earnings, along with reduced poverty.

Table 3: Minnesota Family Investment Program (MFIP): Third-Year Effects

\begin{tabular}{|l|c|c|c|}
\hline & Full a) & Incentive only & $\begin{array}{c}\text { (Employment } \\
\text { services) } \\
(3)=(1)-(2)\end{array}$ \\
\hline Employment (\%) & $(1)$ & $(2)$ & $(7.9)$ \\
Annual earnings (\$) & 11.5 & 3.6 & $(762)$ \\
Annual cash transfers (\$) & 571 & -191 & $(212)$ \\
Annual income (\$) & 614 & 1,165 & $(-4.1)$ \\
Poverty (\%) & 1,185 & 973 & -8.3 \\
\hline a) Income supplement and employment services.
\end{tabular}

Source: Bloom and Michalopoulos (2001), p. 65, column 6; Miller et al. (2000), p. 98: poverty data. 


\section{Conclusion}

Around the world, welfare-to-work policies are on the political agenda. Job search assistance and workfare are important elements of this new policy approach. In spite of the spread of these policies, there is little knowledge of the effects of these two elements. On the basis of the few experimental or econometric evaluations that focus on specific measures, the following conclusions can be deduced.

Non-compulsory job search assistance has its limits because of low take-up rates, although participants are successful in finding work. Sanctions imposed on welfare recipients not complying with job search requirements and a close monitoring and counselling by welfare agencies have a positive effect on participation in job search programmes and on job search behaviour. They increase the transition rate from welfare to work. The number and qualifications of personal advisors are important factors of performance. A high-level strictness of job search requirements may, however, reduce earnings obtained in the new jobs. Welfare recipients with stronger labour market disadvantages need job search assistance more than other persons. Individual counselling is more effective than collective provision of information and counselling which may prevent participants from looking for a job.

Workfare promotes the transition from welfare to work. This is especially true for subsidised private-sector employment. The success of this workfare category is due to the high employability of participants, the close contact to employers and the minor role of locking-in effects. In contrast, public-sector employment is not very effective. Lockingin effects are high, especially for women. Early assignment into public programmes prolongs the welfare spell. Persons with labour market disadvantages need activation more than other welfare recipients.

Now, if job search assistance and workfare are compared, which one is more effective in promoting the transition from welfare to work? Referring to unemployment insurance benefit recipients and using a quantitative model of equilibrium unemployment, Fredriksson and Holmlund (2003) suggest that job search assistance with monitoring and sanctions is superior to workfare because workfare is not conducive to search for a regular job. This is in line with evaluations comparing job search assistance and public sector employment with its high locking-in effects. It is not supported by comparisons with subsidised private sector employment, which does not appear to be inferior to job search assistance.

The effectiveness of work-first programmes vis-à-vis other welfare-to-work measures is evident. Job search programmes seem to be more successful than training programmes. The same is true for workfare programmes at least in the short run. "Mixed" pro- 
grammes that assign some participants to work-first and other participants to training seem, however, to be superior. A combination of mandatory job search assistance with in-work benefits can be useful as well.

Experimental and econometric evaluations allow for a measurement of the direct effects of specific welfare-to-work measures and allow for comparisons between individual instruments. On the other hand, these evaluations are not suited to measure indirect effects and thus the total impact of welfare-to-work policies. Furthermore in most cases, they do not analyse long-term effects and do not include a comprehe nsive cost-benefitanalysis. In addition, these evaluations do not tell us why certain measures have been effective. Often, they do not analyse how the impact of a specific measure is changing when its design is altered. In spite of all these shortcomings, evaluation results provide useful information for the design of welfare-to-work policies. 


\section{References}

Benus, J. M., J. M. Joesch, T. R. Johnson and D. H. Klepinger (1997), Evaluation of the Maryland Unemployment Insurance Work Search Demonstration: Final Report, Batelle Memorial Institute in association with Abt. Associates Inc.

Bitler, M.P., J.B. Gelbach and H.W. Hoynes (2003), "What Mean Impacts Miss: Distributional Effects of Welfare Reform Experiments", NBER Working Paper 10121.

Blank, R. (2002), "Evaluating Welfare Reform in the United States", Journal of Economic Literature, Vol. XL, December, 1105-1166.

Blank, R. (2003), “U.S. Welfare Reform: What's Relevant for Europe?”, CESifo Economic Studies 49 (1), 49-74.

Bloom, D. and Ch. Michalopoulos (2001), How Welfare and Work Policies Affect Employment and Income: A Synthesis of Research, New York, Manpower Demonstration Research Corporation.

Bolvig, I., P. Jensen and M. Rosholm (2003), "The Employment Effects of Active Social Policy", IZA Discussion Paper No. 736, March.

Bolvig, I., P. Jensen and M. Rosholm (2001), Effekter af aktiveringsindsatsen i Århus Kommune, Aarhus.

Calmfors, L., A. Forslund and M. Helmström (2001), "Does Active Labour Market Policy Work? Lessons from the Swedish Experiences", Swedish Economic Policy Review 8, 61-124.

Cancian, M., R. Haveman, D. R. Meyer and B. Wolfe (2003), The Employment, Earnings, and Income of Single Mothers in Wisconsin Who Left Cash Assistance: Comparisons among Three Cohorts, Institute for Research on Poverty, Special Report No. 85, Madison.

Dolton, P. and Y. Balfour (2002), “Der New Deal, 'Welfare to Work'-Programme in Großbritannien”, Perspektiven der Wirtschaftspolitik 3 (2), 175-187.

Dorsett, R. (2001), “The New Deal for Young People: Relative Effectiveness of the Options in Reducing Male Unemployment", PSI Research Discussion Paper 7, London.

Evans, M., J. Eyre, J. Millar and S. Sarre (2003), New Deal for Lone Parents: Second Synthesis Report of the National Evaluation, prepared for the Department for Work and Pensions, Bath.

Fredriksson, P. and B. Holmlund (2003), "Optimal Unemployment Insurance Design: Time Limits, Monitoring, or Workfare?”, CESifo Working Paper No. 1019.

Friedlander, D. and G. Burtless (1995), Five Years After: The Long-Term Effects of Welfare-to-Work Programs, New York. 
Garfinkel, I., C.F. Manski and C. Michalopoulos (1992), "Micro Experiments and Macro Effects", in C.F. Manski and I. Garfinkel, eds., Evaluating Welfare and Training Programs, Cambridge, MA, 253-273.

Gilbert, N. and R. A. van Voorhis (2001), "Introduction", in N. Gilbert and R A. van Voorhis, eds., Activating the Unemployed, A Comparative Appraisal of WorkOriented Policies, New Brunswick, London, vii-xiii.

Graversen, B. K. (2003), The Impact of Active Labour Market Programmes on Welfare Dependence in Denmark, The Danish National Institute of Social Research, Aarhus, mimeo.

Gueron, J. M. and E. Pauly (1991), From Welfare to Work, New York.

Hagen, T. and V. Steiner (2000), Von der Finanzierung der Arbeitslosigkeit zur Förderung von Arbeit, Baden-Baden.

Hales, J., D. Collins, C. Hasluck and S. Woodland (2000), New Deals for Young People and for Long-term Unemployed: Survey of Employers, Employment Service Report ESR 58, Sheffield.

Hamilton, G., S. Freedman, L. Gennetian, C. Michalopoulos, J. Walter, D. AdamsCiardullo, A. Gassman-Pines, S. McGroder, M. Zaslow, J. Brooks and S. Ahluwalia (2001), How Effective Are Different Welfare-to-Work Approaches? Five Year Adult and Child Impacts for Eleven Programs, Washington, DC.

Heckman, J. J., R. J. Lalonde and J. A. Smith (1999), "The Economics and Econometrics of Active Labour Market Programs", in A. Ashenfelter and B. Card, eds., Handbook of Labor Economics 3, 1165-2097.

Hotz, V. J., G. Imbens and J. Klerman (2000), "The Long-Term Gains from GAIN: A Re-Analysis of the Impacts of the California GAIN Program", NBER Working Paper 8007, Cambridge, MA.

Jerger, J., C. Pohnke and A. Spermann (2001), "Gut betreut in den Arbeitsmarkt? Eine mikroökonometrische Evaluation der Mannheimer Arbeitsvermittlungsagentur", Mitteilungen aus der Arbeitsmarkt- und Berufsforschung 34, 567-576.

Lessof, C., M. Miller, M. Phillips, K. Pickering, S. Purdon and J. Hales (2003), New Deal for Lone Parents Evaluation, Findings from the Quantitative Survey, Sheffield: Employment Service (WAE 147).

Lissenburgh, S. (2001), New Deal for the Long-term Unemployed Pilots: Quantitative Evaluation Using Stage 2 Survey, Employment Service Report ESR 81, Sheffield.

Lodemel, I. and H. Trickey (2000),"A New Contract for Social Assistance", in I. Lodemel and H. Trickey, eds., 'An Offer You Can't Refuse', Workfare in International Perspective, Bristol, 1-39.

Martin, J. P. and B. Grubb (2001), "What Works and for Whom: A Review of OECD Countries' Experiences with Active Labour Market Policies", Swedish Economic Policy Review 8, 9-56. 
Miller, C., V. Knox, L. A. Gennetian, M. Dodoo, J. A. Hunter and C. Redcross (2000), Reforming Welfare and Rewarding Work: Final Report on the Minnesota Family Investment Program, Vol. 1: Effects on Adults, New York, Manpower Demonstration Research Corporation.

Ochel, W. (2003), "Welfare to Work in the U.S.: A Model for Germany?", Finanzarchiv 5 (1), 91-119.

OECD (2001), Labour Market Policies and the Public Employment Service, Paris.

OECD (2003), Employment Outlook, Paris.

Orszag, J. M. and D. J. Snower (1999), “Anatomy of Policy Complementarities”, IZA Discussion Paper No. 41.

Peck, J. (2001), Workfare States, New York, London.

Pierson, P. (2001), "Coping with Permanent Austerity Welfare State Restructuring in Affluent Democracies", in P. Pierson, ed., The New Politics of the Welfare State, Oxford, 410-456.

Pohnke, C. (2001), Wirkungs- und Kosten-Nutzen-Analysen, Eine Untersuchung von Maßnahmen der aktiven Arbeitsmarktpolitik am Beispiel kommunaler Beschäftigungsprogramme, Frankfurt am Main.

Schmidt, C. M., K. F. Zimmermann, M. Fertig and J. Kluve (2001), Perspektiven der Arbeitsmarktpolitik, Internationaler Vergleich und Empfehlungen für Deutschland, Berlin, Heidelberg, New York.

Trickey, H. (2000), "Comparing Workfare Programmes - Features and Implications", in I. Lodemel and H. Trickey, eds., 'An Offer You Can't Refuse', Workfare in International Perspective, Bristol, 249-293.

van Berkel, R. and J. de Schampheleire (2001), "The Activation Approach in Dutch and Belgian Social Policies”, Journal of European Area Studies 9 (1), 27-42.

van Berkel, R. (2000), Inclusion through Participation (INPART), Final Report (WP 4), Utrecht.

van Berkel, R., C. Tholen and B. Valkenburg (n.y.), Inclusion and Exclusion in Activating Social Policies: Two Case Studies on the Netherlands, Utrecht.

van den Berg, G. J., B. van der Klaauw and J. C. van Ours (2002), "Punitive Sanctions and the Transition Rate from Welfare to Work", Free University of Amsterdam, Faculty of Economics, Business Administration and Econometrics, Research Memoranda, No. 33.

van den Berg, G. J. and B. van der Klaauw (2003), "Counselling and Monitoring of Unemployed Workers: Theory and Evidence from a Controlled Social Experiment", Free University of Amsterdam Discussion Paper, January.

van Oorschot, W. (2002), "Miracle of Nightmare? A Critical Review of Dutch Activation Policies and their Outcomes", Journal of Social Policy 31(3), 339-420. 
Voges, W. and J. Lemnitzer (2002), "Executive Summary: Germany", in I. Lodemel, ed., Workfare in Six European Nations, Findings from Evaluations and Recommendations for Future Development, Fafo-paper 24, Oslo, 21-27.

Wilkinson, D. (2003), New Deal for People Aged 25 and over: A Synthesis Report, London.

Wiseman, M. (2000), "Making Work for Welfare in the United States", in I. Lodemel and H. Trickey, eds., 'An Offer You Can't Refuse', Workfare in International Perspective, Bristol, 215-247. 


\section{CESifo Working Paper Series}

(for full list see www.cesifo.de)

1087 Lars P. Feld, Gebhard Kirchgässner, and Christoph A. Schaltegger, Decentralized Taxation and the Size of Government: Evidence from Swiss State and Local Governments, November 2003

1088 Arno Riedl and Frans van Winden, Input Versus Output Taxation in an Experimental International Economy, November 2003

1089 Nikolas Müller-Plantenberg, Japan’s Imbalance of Payments, November 2003

1090 Jan K. Brueckner, Transport Subsidies, System Choice, and Urban Sprawl, November 2003

1091 Herwig Immervoll and Cathal O'Donoghue, Employment Transitions in 13 European Countries. Levels, Distributions and Determining Factors of Net Replacement Rates, November 2003

1092 Nabil I. Al-Najjar, Luca Anderlini \& Leonardo Felli, Undescribable Events, November 2003

1093 Jakob de Haan, Helge Berger and David-Jan Jansen, The End of the Stability and Growth Pact?, December 2003

1094 Christian Keuschnigg and Soren Bo Nielsen, Taxes and Venture Capital Support, December 2003

1095 Josse Delfgaauw and Robert Dur, From Public Monopsony to Competitive Market. More Efficiency but Higher Prices, December 2003

1096 Clemens Fuest and Thomas Hemmelgarn, Corporate Tax Policy, Foreign Firm Ownership and Thin Capitalization, December 2003

1097 Laszlo Goerke, Tax Progressivity and Tax Evasion, December 2003

1098 Luis H. B. Braido, Insurance and Incentives in Sharecropping, December 2003

1099 Josse Delfgaauw and Robert Dur, Signaling and Screening of Workers' Motivation, December 2003

1100 Ilko Naaborg, Bert Scholtens, Jakob de Haan, Hanneke Bol and Ralph de Haas, How Important are Foreign Banks in the Financial Development of European Transition Countries?, December 2003

1101 Lawrence M. Kahn, Sports League Expansion and Economic Efficiency: Monopoly Can Enhance Consumer Welfare, December 2003 
1102 Laszlo Goerke and Wolfgang Eggert, Fiscal Policy, Economic Integration and Unemployment, December 2003

1103 Nzinga Broussard, Ralph Chami and Gregory D. Hess, (Why) Do Self-Employed Parents Have More Children?, December 2003

1104 Christian Schultz, Information, Polarization and Delegation in Democracy, December 2003

1105 Daniel Haile, Abdolkarim Sadrieh and Harrie A. A. Verbon, Self-Serving Dictators and Economic Growth, December 2003

1106 Panu Poutvaara and Tuomas Takalo, Candidate Quality, December 2003

1107 Peter Friedrich, Joanna Gwiazda and Chang Woon Nam, Development of Local Public Finance in Europe, December 2003

1108 Silke Uebelmesser, Harmonisation of Old-Age Security Within the European Union, December 2003

1109 Stephen Nickell, Employment and Taxes, December 2003

1110 Stephan Sauer and Jan-Egbert Sturm, Using Taylor Rules to Understand ECB Monetary Policy, December 2003

1111 Sascha O. Becker and Mathias Hoffmann, Intra-and International Risk-Sharing in the Short Run and the Long Run, December 2003

1112 George W. Evans and Seppo Honkapohja, The E-Correspondence Principle, January 2004

1113 Volker Nitsch, Have a Break, Have a ... National Currency: When Do Monetary Unions Fall Apart?, January 2004

1114 Panu Poutvaara, Educating Europe, January 2004

1115 Torsten Persson, Gerard Roland, and Guido Tabellini, How Do Electoral Rules Shape Party Structures, Government Coalitions, and Economic Policies? January 2004

1116 Florian Baumann, Volker Meier, and Martin Werding, Transferable Ageing Provisions in Individual Health Insurance Contracts, January 2004

1117 Gianmarco I.P. Ottaviano and Giovanni Peri, The Economic Value of Cultural Diversity: Evidence from US Cities, January 2004

1118 Thorvaldur Gylfason, Monetary and Fiscal Management, Finance, and Growth, January 2004

1119 Hans Degryse and Steven Ongena, The Impact of Competition on Bank Orientation and Specialization, January 2004 
1120 Piotr Wdowinski, Determinants of Country Beta Risk in Poland, January 2004

1121 Margarita Katsimi and Thomas Moutos, Inequality and Redistribution via the Public Provision of Private Goods, January 2004

1122 Martin Peitz and Patrick Waelbroeck, The Effect of Internet Piracy on CD Sales: CrossSection Evidence, January 2004

1123 Ansgar Belke and Friedrich Schneider, Privatization in Austria: Some Theoretical Reasons and First Results About the Privatization Proceeds, January 2004

1124 Chang Woon Nam and Doina Maria Radulescu, Does Debt Maturity Matter for Investment Decisions?, February 2004

1125 Tomer Blumkin and Efraim Sadka, Minimum Wage with Optimal Income Taxation, February 2004

1126 David Parker, The UK's Privatisation Experiment: The Passage of Time Permits a Sober Assessment, February 2004

1127 Henrik Christoffersen and Martin Paldam, Privatization in Denmark, 1980-2002, February 2004

1128 Gregory S. Amacher, Erkki Koskela and Markku Ollikainen, Deforestation, Production Intensity and Land Use under Insecure Property Rights, February 2004

1129 Yin-Wong Cheung, Javier Gardeazabal, and Jesús Vázquez, Exchange Rate Dynamics: Where is the Saddle Path?, February 2004

1130 Alberto Alesina and Guido Tabellini, Bureaucrats or Politicians?, February 2004

1131 Gregory S. Amacher, Erkki Koskela, and Markku Ollikainen, Socially Optimal Royalty Design and Illegal Logging under Alternative Penalty Schemes, February 2004

1132 David M. Newbery, Privatising Network Industries, February 2004

1133 Charles Yuji Horioka, The Stagnation of Household Consumption in Japan, February 2004

1134 Eiji Fujii, Exchange Rate Pass-Through in the Deflationary Japan: How Effective is the Yen's Depreciation for Fighting Deflation?, February 2004

1135 Mark M. Spiegel and Nobuyoshi Yamori, Determinants of Voluntary Bank Disclosure: Evidence from Japanese Shinkin Banks, Febrary 2004

1136 Robert Dekle and Kenneth Kletzer, Deposit Insurance, Regulatory Forbearance and Economic Growth: Implications for the Japanese Banking Crisis, February 2004

1137 Takatoshi Ito and Kimie Harada, Bank Fragility in Japan, 1995-2003, February 2004 
1138 Kunio Okina and Shigenori Shiratsuka, Policy Duration Effect under Zero Interest Rates: An Application of Wavelet Analysis, February 2004

1139 Francine D. Blau and Lawrence M. Kahn, Do Cognitive Test Scores Explain Higher U.S. Wage Inequality?, February 2004

1140 Michael Rauscher, Economic Growth and Tax-Competing Leviathans, February 2004

1141 Ernst Fehr and Jean-Robert Tyran, Money Illusion and Coordination Failure, February 2004

1142 Ingo Vogelsang, Network Utilities in the U.S. - Sector Reforms without Privatization, March 2004

1143 Marc-Andreas Muendler, Estimating Production Functions When Productivity Change is Endogenous, March 2004

1144 Sascha O. Becker, Samuel Bentolila, Ana Fernandes, and Andrea Ichino, Job Insecurity and Children's Emancipation, March 2004

1145 Pascalis Raimondos-Møller and Alan D. Woodland, Non-Preferential Trading Clubs, March 2004

1146 Robert Fenge and Matthias Wrede, EU Regional Policy: Vertical Fiscal Externalities and Matching Grants, March 2004

1147 Chi-Yung Ng and John Whalley, Geographical Extension of Free Trade Zones as Trade Liberalization: A Numerical Simulation Approach, March 2004

1148 Marc-Andreas Muendler, Trade, Technology, and Productivity: A Study of Brazilian Manufacturers, 1986-1998, March 2004

1149 Eugene Beaulieu, Vivek H. Dehejia, and Hazrat-Omar Zakhilwal, International Trade, Labour Turnover, and the Wage Premium: Testing the Bhagwati-Dehejia Hypothesis for Canada, March 2004

1150 Giorgio Brunello and Francesca Gambarotto, Agglomeration Effects on EmployerProvided Training: Evidence from the UK, March 2004

1151 S. Brock Blomberg, Gregory D. Hess, and Athanasios Orphanides, The Macroeconomic Consequences of Terrorism, March 2004

1152 Bodo Sturm and Joachim Weimann, Unilateral Emissions Abatement: An Experiment, March 2004

1153 Wolfgang Ochel, Welfare-to-Work Experiences with Specific Work-First Programmes in Selected Countries, March 2004 